\title{
PIERRE BOURDIEU, LANGUAGE AND SYMBOLIC POWER,
}

\author{
Eka Ningtyas \\ Pascasarjana Sejarah UGM
}

\begin{abstract}
Judul: Language and Symbolic Power | Penulis: Pierre Bourdieu |
Penerbit: Polity Press, Malden | Tahun: 2007 | Tebal: 302 halaman
\end{abstract}

P ierre Bourdieu adalah pemikir sosial yang fokus pada kajian bahasa sebagai instrumen tindakan atau praktik sosial. Ide-ide besarnya dapat dikatakan melampaui jaman. Hidup dalam tradisi kuat strukturalisme a la Ferdinand de Saussure yang mempengaruhi sebagian besar pemikir sosial Perancis pada tahun 1960-an, tidak membuat Bourdieu memilih jalan yang sama. Penafsirannya tentang bahasa tidak sebatas pada aspek internal bahasa dan menegasikan kondisi sosial-historis pembuatan dan penerimaan teks. Menurutnya hubungan antara individu dan masyarakat bukan merupakan reduksi dari langue dan parole yang menjadi pilar penyangga teori strukturalisme. Langue mengacu pada tanda sedangkan parole mengacu pada penanda. Hubungan langue dan parole ini menghasilkan oposisi biner yang memisahkan individu dan masyarakat, dan sekaligus menjadikan langue sebagai obyek otonom ilmu linguistik. Fungsi parole direduksi hanya sebatas subyek penutur, dan dalam kacamata pemikiran Saussure subyek penutur ini bebas nilai, keberadaannya sebagai pelaku sosial tidak diperhitungkan.

\section{Langue dan Parole dalam Kacamata Bourdieu}

Bourdieu pada bagian awal buku ini memaknai berbeda teori strukturalisme Ferdinand de Saussure dan Noam Chomsky. Terdapat perbedaan mendasar pendekatan teoretikal yang disajikan oleh teori Saussure dan Chomsky, sebagai contoh pendekatan
Chomsky lebih dinamis dan memberi perhatian lebih pada penutur bahasa. Tetap saja menurut pandangan Bourdieu, keduanya masih meletakkan dasar pemikiran pada pemisahan fundamental yang memungkinkan bahasa dibentuk menjadi sebuah obyek otonom dan homogen, serta mengingkari kondisi sosiohistoris yang melatarbelakangi praktik bahasa.

Proses sosio-historis ini dijelaskan oleh Bourdieu secara hati-hati melalui proses pembentukan sosial, sejarah, kondisi politik, kondisi geografis tertentu, juga berkaitan dengan formasi modern negara-bangsa. Dalam kasus ini Bourdieu mengangkat peristiwa di Perancis telah terjadi proses penyatuan linguistik terkait dengan pembangunan negara monarki pasca Revolusi Perancis (hlm. 49). Ada perbedaan nyata antara kelas buruh dan kelas bangsawan dalam pemilihan kata, antara mulut rapat (la bouche) dan mulut terbuka (la gueule). La bouche diasosiasikan dengan sifat borjuis dan feminin, sedangkan la gueula diasosiasikan dengan sifat popular dan maskulin. (hlm 46) Sehingga dalam pandangan Bourdieu, bahasa adalah bentuk praktik sosial karena di dalamnya berisikan hubungan yang kompleks antara penutur bahasa dengan latarbelakang sosiohistorisnya.

Pandangan itu diperolehnya dari refleksi pengalaman pribadinya sebagai seseorang yang berasal dari daerah pinggiran Perancis yaitu Denguin, Pyrenia Atlantik. Pada tahun 1951, Bourdieu masuk di sekolah tinggi 


\section{Jurnal Poetika Vol. III No. 2, Desember 2015}

prestisius, Ecole Normale Supérieure, yang juga merupakan tempat pemikir-pemikir besar berasal seperti Sartre, Foucault, Levinas, pernah menuntut ilmu. Latarbelakangnya sebagai anak seorang pegawai kantor pos membuatnya kesulitan mengikuti teman kuliahnya yang sebagian besar berasal dari keluarga kelas atas di Perancis. Bourdie menyadari bahwa seseorang dipengaruhi oleh habitus yang diperoleh dari pengkondisian yang dikaitkan dengan syarat-syarat keberadaan suatu kelas sosial tertentu. Habitus merupakan hasil akumulasi keterampilan yang menjadi tindakan praktis dan diterjemahkan menjadi suatu kemampuan yang nampak alamiah.

\section{Habitus sebagai Kritik atas Teori Strukturalisme}

Pada bagian kedua buku ini, Bourdieu memberikan prespektif kritis terhadap kerja dari Saussure, Chomsky, Austin dan yang lain, dan memperkenalkan konsep habitus. Jika pada teori strukturalisme yang dikembangkan oleh Saussure, menegasikan pengalaman sosiohistoris dan menjadikan langue sebagai kajian utama dari bahasa, maka konsep habitus yang diperkenalkan Bourdieu menjawab kekurangan dari teori strukturalisme. Logika yang digunakan Bourdieu ketika memposisikan pentingnya melihat parole dalam hubungan individu dengan masyarakat, membuka pada konsep-konsep Bourdieu yang lain seperti arena, kapital, kekuasaan simbolik dan kekerasan simbolik.

Individu sebagai parole dalam hubungannya dengan masyarakat sebagai langue, menurut pandangan Bourdieu berkaitan dengan otoritas yang menunjukkan efektivitas sebuah ujaran performatif. Ini tidak dapat dipisahkan dari adanya institusi yang menentukan kondisi agar ujaran menjadi benar-benar efektif. Pada level ini Bourdieu sekaligus mengkritik teori J.L. Austin mengenai teori tutur tindak (speech act theory). Austin dalam teorinya lupa bahwa efektivitas sebuah ujuran tidak dapat dilepaskan dari institusi yang memberikan otoritas kepada penutur untuk melakukan tindakan sebagaimana dalam ujaran performatif. Austin tidak mengembangkan lebih lanjut bahwa otoritas yang dimiliki oleh pelaku sosial tidak muncul begitu saja, tapi berbentuk investasi sosial (hlm. 78). Otoritas ini yang disebut oleh Bourdiue sebagai kapital simbolik. Direpresentasikan dan dimanifestasikan oleh bahasa sehingga bahasa erat kaitannya dengan kekuasaan simbolik.

Konsep lain yang terkenal dari Bourdieu adalah mengenai empat bentuk perbedaan kapital. Tidak hanya kapital ekonomi dalam makna kaku (seperti contoh bentuk kemakmuran, uang, kekayaan), namun juga kapital budaya (seperti keahlian, dan kepintaran), kapital sosial (jaringan, hubungan bisnis, hubungan sosial dalam masyarakat), dan juga kapital simbolik (seperti kebanggaan, prestis) (hlm.109). Kepemilikan keempat kapital ini tentu saja memberikan pengaruh pada habitus seseorang. Anak seorang professor (yang orang tuanya memiliki kapital budaya yang tinggi) tentu memiliki habitus yang berbeda dengan anak seorang pedagang kaki lima (sedikit memiliki kapital budaya). Pemilihan diksi ketika berkomunikasi dalam masyarakat (langue) akan menunjukkan diferensiasi, diantara kedua anak itu. Sekali lagi Bourdieu mengingatkan, tidak cukup berbekal kapital saja untuk dapat memaksimalkan komunikasi dalam arena, namun juga penting melihat strategi penempatan. Strategi penempatan adalah maksimalisasi kapital yang dimiliki pada sebuah arena sosial tertentu dalam waktu yang tepat. Arena adalah konsep yang lain dari Bourdieu tentang dunia sosial, sebagai bentuk 'bagian kecil' dunia sosial, penuh mufakat yang bekerja secara otonom dengan hukumnya sendiri, misal arena politik, seni, agama dan sebagainya (hlm. 163).

Terminologi yang digunakan Bourdieu untuk menjelaskan "arena" dan hal-hal di dalamnya seperti "pasar", "kapital", "keuntungan" adalah istilah yang dipinjam dari bahasa ekonomi. Istilah itu diadaptasi untuk 


\section{Jurnal Poetika Vol. III No. 2, Desember 2015}

menganalisa "arena" yang sama sekali bukan dalam sense ekonomi. Lebih untuk menjelaskan jalur kekuasaan simbolis yang berkelindan dengan kekerasan simbolik.

\section{Bahasa: Kekuasaan Simbolik dan Kekerasan Simbolik}

Akumulasi dari kapital yang dimiliki (ekonomi, sosial, budaya, dan simbolik) menghasilkan wacana dominan atau yang dikenal dengan istilah doxa. Dalam kaitannya dengan kekuasaan, selalu menghasilkan hubungan dialektis unsur beterodoxa dan orthodoxa. Heterodoxa adalah hal-hal yang sifatnya kontradoxa, berusaha untuk menggulingkan wacana dominan dengan membawa wacana yang baru. Sedangkan orthodoxa adalah pendukung doxa dalam kaitannya dengan usaha menjaga legitimasi yang dimiliki oleh wacana dominan.

Menurut Bourdieu, dari keempat jenis kapital, kapital ekonomi merupakan yang paling mudah dikonversikan dalam bentuk lain, sedangkan kapital simbolik adalah yang paling mulia. Kapital simbolik menghasilkan kekuasaan simbolik disaat orang tidak merasa keberatan untuk masuk dalam dominasi simbolik. Kekerasan simbolik dapat berjalan karena adanya mekanisme kekerasan simbolik melalui dua cara yaitu, eufimisme dan sensorisme (hlm. 145). Eufimisme adalah kondisi dimana kekerasan simbolik tidak tampak, bekerja secara halus, dan tidak dapat dikenali, sedangkan sensorisme menjadikan kekerasan simbolik sebagai bentuk pelestarian semua nilai yang dianggal "moral kehormatan".

Bourdieu melihat disinilah letak inti hubungan bahasa dan mekanisme kekuasaan simbolik. Pada kehidupan sehari-hari kekuasaan simbolik jarang nampak dalam bentuk kekuatan fisik, namun lebih pada bentuk simbolik. Hal itu mencirikan bentuk legitimasi yang tidak dimiliki oleh semua orang. Bourdieu mengekspresikan poin ini dengan mengatakan bahwa kekuasaan simbolik adalah "kekuasaan yang tidak nampak" (invisible power).

Konsep kekuasaan simbolik dan kekerasan simbolik Bourdieu dikembangkan dalam konteks menganalisis pertukaran hadiah di masyarakat Kabylia. Bourdieu tidak menganalisis pertukaran hadiah menggunakan struktur timbal balik Levi-Strauss. Bourdieu lebih memandangnya sebagai mekanisme dimana kekuasaan dilaksanakan sekaligus menyamar. Dalam masyarakat Kabylia, hanya ada relatif sedikit lembaga yang hubungan dominasinya dapat diberikan dalam bentuk stabil dan obyektif, individu harus menggunakan cara-cara yang lebih personal dalam menjalankan kekuasaan atas orang lain. Salah satu bentuk sarana kekuasaan adalah dengan hutang : seseorang dapat membuat orang lain berada "dibawah kekuasaannya" melalui kewajiban membayar hutang. Namun Bourdieu mengatakan, ada cara yang lebih halus dari sarana hutang sebagai bentuk kekuasaan simbolik, yaitu dengan pemberian hadiah.

Melalui pemberian hadiah, terutama yang tidak bisa dikembalikan dengan kualitas seimbang dari si pemberi, maka si penerima akan terikat dalam hubungan hutang budi. Dalam hal ini dapat dikatakan, memberi juga merupakan cara untuk memiliki, dengan cara mengikat orang lain dan menyelubungi obligasi melalui sikap kedermawaan. Inilah apa yang disebut oleh Bourdieu sebagai "kekerasan simbolik", kontras dengan kekerasan terbuka dari lintah darat. Bentuk kekerasan simbolik itu 'lembut', 'kekerasan yang tidak terikat', 'kekerasan yang dibatinkan dalam sikap-sikap kepercayaan, kewajiban, loyalitas pribadi, hadiah, utang, kesalehan, yang semua itu merupakan bentuk kebaikan dalam etika kehirmatan. (hlm. 168).

Logika yang ditawarkan Bourdieu dapat pula dikontekstualisasi untuk menjelaskan kondisi masyarakat industri modern seperti Amerika Serikat atau Eropa. bedanya, jika masyarakat Kabylia masih dalam bentuk institusi yang sederhana, maka kekerasan simbolik dalam masyarakat modern, penting 
memperhatikan mekanisme simbolik untuk mempertahankan dominasi melalui hubungan interpersonal telah mengalami penurunan (hlm. 194). Pengembangan institusi memungkinkan berbagai jenis modal yang akan terakumulasi dan disesuaikan berbeda-beda, sedangkan pengeluaran dan kebutuhan individu untuk mengejar strategi ditujukan langsung pada dominasi lain : kekerasan dibangun dalam isntitusi itu sendiri.

Menurut Bourdieu, sistem pendidikan dapat menjadi contoh yang baik bagaimana kekuasaan simbolik diproduksi dalam masyarakat. Pengembangan sistem ini melibatkan jenis tertentu obyektifikasi dimana kepercayaan didefinisikan secara formal atau kualifikasi menjadi mekanisme untuk menciptakan dan mempertahankan ketidaksetaraan, sedemikian rupa menunjukkan bahwa bentuk "kekuatan terang-terangan" sudah tidak diperlukan. 